\title{
OPTIMASI SUHU DAN WAKTU PROSES PADA EKSTRAKSI GELATIN DARI TULANG IKAN BANDENG (Chanos chanos)
}

\author{
Eni Budiyati dan Vicka Haningtyas \\ Program Studi Teknik Kimia, Fakultas Teknik, Universitas Muhammadiyah Surakarta \\ Jl. A. Yani Pos I Pabelan, Kartasura, Surakarta 57102, Jawa Tengah, Indonesia \\ E-mail:eb112@ums.ac.id
}

Received : 26 April 2020; revised : 5 Juni 2020; accepted : 27 November 2020

\begin{abstract}
ABSTRAK
OPTIMASI SUHU DAN WAKTU PROSES PADA EKSTRAKSI GELATIN DARI TULANG IKAN BANDENG (Chanos Chanos). Gelatin merupakan senyawa yang terdiri atas 50,5\% karbon, $17 \%$ nitrogen, 6,8\% hidrogen, dan $25,2 \%$ oksigen. Senyawa ini merupakan campuran dari protein dan peptida yang dapat dihasilkan dari proses ekstraksi kolagen hewan. Pemanfaatan gelatin dalam berbagai industri, yaitu industri makanan dan minuman, industri fotografi, farmasi, kecantikan, dan industri kimia lainnya. Pemilihan tulang ikan bandeng sebagai bahan baku penelitian karena jumlahnya yang relatif banyak dan belum diimbangi oleh pengolahan terhadap limbah tulang ikan bandeng tersebut. Penelitian ini bertujuan untuk mengekstraksi gelatin dari tulang ikan bandeng (Chanos chanos). Di samping itu, studi ini juga mengevaluasi pengaruh suhu dan ekstraksi terhadap karakteristik gelatin yang dihasilkan. Tulang ikan bandeng diekstraksi dalam gelas beker dan diaduk dengan kecepatan pengadukan yang konstan, yaitu sekitar $520 \mathrm{rpm}$. Variasi suhu yang diinvestigasi adalah $50^{\circ} \mathrm{C}, 70^{\circ} \mathrm{C}$, dan $90^{\circ} \mathrm{C}$. Sedangkan variasi waktu ektraksi yang digunakan adalah 1,5 jam, 2 jam, 2,5 jam, dan 3 jam. Rendemen gelatin tertinggi diperoleh pada suhu $70^{\circ} \mathrm{C}$ dan waktu ekstraksi 2,5 jam, yaitu sekitar $2,43 \%$. Sedangkan karakteristik hasil penelitian terbaik diperoleh pada suhu $70^{\circ} \mathrm{C}$, dan waktu reaksi 2 jam dengan kadar air $8 \%$, kadar abu $2 \%$, viskositas 2,237 cP, dan $\mathrm{pH} 4,2$. Hasil gelatin ini diaplikasikan pada pembuatan resep sirup. Gelatin tulang ikan bandeng dengan konsentrasi 7\%/L dibutuhkan untuk memperoleh viskositas sirup yang sama dengan sirup komersial.
\end{abstract}

Kata kunci : gelatin, tulang ikan bandeng, ekstraksi, suhu, waktu.

\begin{abstract}
OPTIMIZATION OF TEMPERATURE AND PROCESSING TIME ON THE EXTRACTION OF GELATIN FROM THE MILKFISH BONES (Chanos Chanos). Gelatin is a compound consisting of $50.5 \%$ carbon, $17 \%$ nitrogen, $6.8 \%$ hydrogen, and $25.2 \%$ oxygen. This compound is a mixture of proteins and peptides that can be produced from the extraction of animal collagen. Utilization of gelatin in various industries, namely food and beverage, pharmaceutical, beauty, and other chemical industry. Selection of milkfish bones as raw material because of the numbers and has not been balanced by the treatment of the milkfish bones waste. The study purposed to extract gelatin from the milkfish (Chanos chanos) bones. In addition, this study also evaluated the influence of the extraction time and temperature to the resulted gelatin characteristics. The milkfish bones were extracted in a beaker glass and stirred with a constant stirring speed, which was about $520 \mathrm{rpm}$. The investigated temperature variations were $50^{\circ} \mathrm{C}, 70^{\circ} \mathrm{C}$, and $90^{\circ} \mathrm{C}$. While, the used variation of extraction time were 1.5 hours, 2 hours, 2.5 hours, and 3 hours. The highest gelatin recovery rate was obtained at temperature of $70{ }^{\circ} \mathrm{C}$ time for 2.5 hours, which was around $2.43 \%$. Meanwhile, the best research result characteristics was obtained at a temperature of $70{ }^{\circ} \mathrm{C}$, and a reaction time of 2 hours with a moisture content of $8 \%$, ash content of $2 \%$, viscosity of $2.237 \mathrm{cP}$, and $\mathrm{pH}$ of 4.2. The result of this gelatin was applied to the manufacture of syrup recipes. Bandeng fish bone gelatin with a concentration of $7 \% / L$ was required to obtain the same syrup viscosity as commercial syrup.
\end{abstract}

Key words : Gelatin, milkfish bones, extraction, temperature, time.

\section{PENDAHULUAN}

Gelatin banyak digunakan secara luas dalam berbagai industri, yaitu industri makanan dan minuman, industri fotografi, farmasi, kecantikan, dan industri kimia lainnya karena memiliki sifat fungsional yang unik (Karim and Bhat, 2009). Di dalam industri makanan, gelatin dimanfaatkan sebagai stabilizer (bahan penstabil), gelling agent (pembentuk gel), binder agent (pengikat), adhesive (perekat), emulsifier (pengemulsi), dan viscosity agent (zat peningkat viskositas). Sedangkan dalam industri farmasi, gelatin sering digunakan sebagai plasma expander, pengikat pastilles dan tablet, surgical powder, pembuat kapsul, dan mikroenkapsulasi. 
Gelatin juga dimanfaatkan sebagai sebagai sizing paper (industri kertas) dan pengikat bahan peka cahaya (industri fotografi).

Gelatin mengandung berbagai jenis asam amino dan memiliki nilai nutrisi yang sangat baik. Asam-asam amino ini berkontribusi dalam berbagai fungsi termasuk antioksidan, antihipertensi, antimikroba, regenerasi jaringan dan penyembuhan luka promosi, pembentukan tulang peningkatan, dan aplikasi anti kanker (Aleman and Martinez-Alvarez, 2013).

Kandungan asam amino dalam gelatin antara lain 35\% glisin, 21\% (prolin dan hidroksiprolin), dan $11 \%$ alanin (Richard and Albert, 2008). Gelatin terdiri atas 50,5\% karbon, $25,2 \%$ oksigen, $17 \%$ nitrogen, dan 6,8\% hidrogen. Senyawa ini merupakan campuran dari protein dan peptida yang dapat dihasilkan dari proses ekstraksi kolagen hewan (pada jaringan ikat, tulang, dan kulit) (Hanani, 2015).

Bahan baku gelatin diperoleh dari tulang, kulit dan jaringan ikat yang terdapat pada hewan. Selama ini sumber bahan baku gelatin berasal dari tulang sapi maupun babi. Negara tertentu seperti India, terdapat umat Hindu yang melarang masyarakatnya mengkonsumsi sapi sedangkan umat Islam dilarang mengkonsumsi babi. Kondisi tersebut membuka alternatif bahan baku pembuatan gelatin yaitu menggunakan tulang atau kulit ikan. Tulang ikan mengandung kadar kolagen yang cukup tinggi dan potensial untuk diproses lebih lanjut.

Kolagen merupakan protein berserat yang ditemukan di semua organisme multisel. Kolagen protein yang paling banyak terdapat mamalia, yaitu sekitar 25\% - 30\% dari jumlah semua protein yang terdapat pada jaringan dan organ tubuh invertebrata dan vertebrata (Richard and Albert, 2008).

Kolagen mempunyai sifat insoluble dalam larutan asam maupun basa dan mempunyai ketahanan terhadap enzim chimotripsin dan tripsin. Kolagen dapat menyusut atau mengkerut apabila terkena suhu tinggi (panas). Apabila pemanasannya dilakukan sampai suhu $\geq 52^{\circ} \mathrm{C}$ (suhu pengkerutannya), maka kolagen akan terkonversi menjadi gelatin (Schrieber and Gareis, 2007). Hal ini juga diperkuat oleh hasil penelitian yang menyatakan bahwa apabila kolagen dipanaskan sampai mendidih, maka struktur kolagen tersebut akan rusak secara permanen dan terkonversi menjadi gelatin (Katili, 2013).

Menurut Standar Gelatin Manufacturers Institute of America (GMIA) Tahun 2012, gelatin mempunyai karakteristik seperti yang ditunjukkan pada Tabel 1.

Tabel 1. Karakkteristik Gelatin Berdasarkan Standar GMIA (2012)

\begin{tabular}{cc}
\hline Karakteristik & Tipe A \\
\hline Kekuatan gel (bloom) & $50-300$ \\
Titik isoelektrik & $7-9$ \\
pH & $3,8-5,5$ \\
Kadar abu (\%) & $0,3-2$ \\
Kadar air (\%) & $8-13$ \\
Viskositas (cPs) & $1,5-7,5$ \\
Warna & Tidak berwarna \\
\hline
\end{tabular}

Sirup merupakan larutan gula pekat yang ditambahi maupun tidak ditambahi zat aditif makanan yang diijinkan (GMIA, 2012). Gelatin akan diaplikasikan ke minuman yaitu sebagai pengental sirup, sesuai dengan fungsinya yaitu sebagai pengental (emulsifier).

Beberapa penelitian terdahulu tentang pengambilan gelatin dari ikan antara lain sisik ikan kadal (Chen et al., 2018), kulit ikan tuna (Haddar et al., 2012), kulit ikan Mola (Zhang et al., 2018), kulit cold-water fish (Temofeew et al., 2017), sisik ikan gabus (Channa argus) (Chun et al., 2016), ikan nila hitam (Jamilah and Harvinder, 2002), ikan salmon (Neves et al., 2017), dan ikan hiu biru (Prionace glauca) (Elango et al., 2016). Sedangkan Huang et al. telah melakukan penelitian tentang gelatin dari ikan bandeng. Dalam penelitian tersebut diperoleh hasil bahwa perlakuan awal (pretreatment) ekstrusi dapat meningkatkan rendemen dan efisiensi gelatin yang diperoleh (Huang et al., 2018).
Penerapan temuan ini bisa bermanfaat secara ekonomi dalam industri makanan dan perikanan. Meskipun gelatin ikan telah menjadi fokus penelitian sejak awal 1960-an, namun efisiensi ekstraksi dan penerapan gelatin ikan masih scalable dan masih memiliki banyak ruang untuk perbaikan (Liu et al., 2015).

Bandeng (Chanos chanos) adalah jenis ikan yang dipelihara di tambak-tambak air payau. Masyarakat sering mengkonsumsi ikan bandeng karena selain harganya relatif murah, ikan tersebut juga memiliki kandungan protein yang tinggi. Tulang ikan bandeng menarik untuk dikaji lebih lanjut sebagai bahan pembuatan gelatin. Hal ini disebabkan oleh pengembangan produk bandeng tanpa duri segar (milkfish boneless) yang semakin meningkat. Sebagai efeknya, jumlah limbah tulang ikan bandeng cukup melimpah (Masirah, 2018). Usaha bandeng tulang lunak memiliki tingkat keberhasilan yang tinggi dan layak untuk dikembangkan keberlanjutannya. Bentuk usaha 
dapat dalam skala kecil, menengah, maupun besar (Candra and Setiawan, 2013).

Penelitian ini bertujuan untuk membuat gelatin dengan tulang ikan bandeng sebagai bahan baku. Pemilihan tulang ikan bandeng dikarenakan ketersediaan jumlah ikan bandeng yang relatif banyak dan kurangnya pengolahan limbah tulang ikan bandeng tersebut. Penelitian ini diharapkan dapat meningkatkan nilai dari limbah tulang ikan bandeng sekaligus mengurangi masalah pencemaran lingkungan. Proses pembuatan gelatin ini akan menitikberatkan pada bagian tahapan ekstraksi, yaitu mempelajari tentang pengaruh suhu dan waktu terhadap rendemen gelatin, kadar abu, dan kadar air gelatin yang dihasilkan. Hidayat et.al. melakukan ektraksi pada tulang ikan nila dengan hasil rendemen $6,30 \%$; kadar protein $86,46 \%$; dan kadar air 7,12 \% (Hidayat et.al., 2016).

\section{BAHAN DAN METODE}

\section{Bahan}

Tulang ikan bandeng (Chanos chanos) diperoleh dari Semarang, Jawa Tengah. Sedangkan, asam asetat (AR Grade) dan aquadest dibeli dari PT. BRATACHEM, Solo. Gula pasir dan resep sirup dibeli dari Pasar Gedhe, Solo.

Alat-alat yang digunakan dalam penelitian ini antara lain labu ukur, gelas beker, kompor listrik, klem dan statif, viskometer, gelas ukur, oven, pengaduk magnetik, pipet ukur, gunting, saringan, panci, kain saring, desikator, termometer, kertas label, isolasi plastik, botol plastik, pHmeter, martil, baskom, dan cawan porselin, dan aluminium foil paper

\section{Metode}

Penelitian ini dilakukan dengan beberapa tahapan yakni degreasing, demineralisasi, ekstraksi dan analisa produk.

\section{Degreasing}

Tulang ikan bandeng 1,6 kg dibersihkan, direndam dalam air mendidih dengan rasio berat air dan tulang ikan sebesar 1,5:1. Perendaman ini dilakukan selama kurang lebih 0,5 jam, dan tulang ikan dipotong sampai ukuran sekitar 1-2 cm. Kemudian, pengeringan tulang ikan dilakukan secara manual dengan sinar matahari selama 1 hari sampai kering.

\section{Demineralisasi}

Tulang ikan sebanyak 100 gram dimasukkan ke dalam baskom. Kemudian larutan asam asetat berkadar $10 \%$ ditambahkan ke dalam baskom tersebut. Larutan asam ini digunakan untuk perendaman selama 24 jam sampai berubah menjadi tulang lunak (ossein). Setelah itu, tulang lunak ini disaring dan dicuci berulang kali dengan aquadest sampai tercapai pH mendekati netral.

\section{Ekstraksi}

Tulang lunak dimasukkan ke dalam gelas beker dan diekstraksi menggunakan pelarut aquadest. Berat aquadest yang digunakan adalah tiga kali $(3 x)$ berat tulang lunaknya. Pengadukan dilakukan secara konstan dengan kecepatan sekitar 520 rpm. Variabel yang dievaluasi adalah suhu dan waktu. Suhu divariasikan pada $50^{\circ} \mathrm{C}, 70^{\circ} \mathrm{C}, 90^{\circ} \mathrm{C}$ dan waktu divariasikan pada 1,5 jam, 2 jam, 2,5 jam dan 3 jam. Kain saring digunakan untuk menyaring hasil ekstraksi. Filtrat yang dihasilkan dimasukkan ke dalam gelas beker yang dilengkapi dengan penangas air pada suhu $80^{\circ} \mathrm{C}$ sampai volume filtrat menjadi pekat, yaitu volume yang tersisa sekitar $25 \mathrm{~mL}$.

\section{Pengeringan}

Cairan pekat dikeringkan di dalam oven selama 6 jam pada suhu $80^{\circ} \mathrm{C}$ sampai diperoleh gelatin kering. Kemudian, bahan yang sudah kering dihaluskan hingga didapat serbuk gelatin dengan ukuran sesuai dengan yang diinginkan.

\section{Analisis Produk}

Analisis produk yang dilakukan adalah rendemen (AOAC, 2016), kadar air, kadar air, analisis FTIR. Analisis karakterisasi sampel dilakuan dengan spektrometer FTIR Shimadzu pada panjang gelombang $4000 \mathrm{~cm}^{-1}-500 \mathrm{~cm}^{-1}$, yang dilakukan di Jurusan Kimia, FMIPA UNS, Surakarta.

\section{Rendemen (AOAC, 2016)}

Penentuan nilai rendemen gelatin tulang ikan Bandeng dapat dilakukan dengan menggunakan persamaan (1):

$$
\text { Rendemen }=\frac{\text { berat kering gelatin }}{\text { berat kering tulang ikan }} \times 100 \%
$$

Kadar air (Marzuki et.al., 2011)

Cawan porselin dikeringkan di dalam oven selama 1 jam pada suhu $105^{\circ} \mathrm{C}$. Setelah itu cawan diambil, didinginkan dalam desikator dan ditimbang. Sampel dimasukkan ke dalam cawan porselin dan dikeringkan di dalam oven. Suhu pengovenan diset $105^{\circ} \mathrm{C}$. Pengeringan dilakukan sampai tercapai berat konstan. Penentuan kadar air dilakukan dengan menggunakan persamaan (2):

$$
\text { Kadar air (\%) }=\frac{A-B}{\text { berat sampel }} \times 100 \%
$$

Keterangan :

$A$ = berat cawan porselin + sampel

$\mathrm{B}=$ berat cawan porselin + sampel setelah dioven 
Kadar abu (Marzuki, et. al., 2011)

Sampel dipanaskan ke dalam tanur bersuhu $550^{\circ} \mathrm{C}$. Sampel diambil setelah waktu pemanasan 3 jam, kemudian didinginkan dalam desikator dan ditimbang. Perhitungan kadar abu dilakukan dengan persamaan (3):

Kadar abu (\%) $=\frac{A-B}{\text { berat sampel }} \times 100 \%$

Keterangan :

$A=$ berat cawan porselin + sampel setelah dipanaskan

$B$ = berat cawan porselin

Analisis FTIR

Analisis FTIR dilakukan di Lab MIPA UNS.

\section{Pengaplikasian pada sirup}

Membuat sirup dengan resep sirup yang didapat dari pasaran. Membuat dua sampel, satu sampel ditambahkan gelatin, dan yang lainnya tanpa penambahan gelatin. Kemudian, membandingkan hasil kedua sirup.

\section{HASIL DAN PEMBAHASAN}

Rendemen dari hasil gelatin untuk variasi suhu dan waktu ekstraksi dihitung dengan metode AOAC, 2012. Berdasarkan gambar 1 diperoleh rendemen gelatin sebesar $2,43 \%$ pada suhu $70^{\circ} \mathrm{C}$ dan waktu ekstraksi 2,5 jam. Sedangkan, rendemen yang diperoleh pada suhu $50^{\circ} \mathrm{C}$ dan waktu 1,5 jam adalah sekitar $0,23 \%$. Penurunan rendemen terjadi pada suhu $90^{\circ} \mathrm{C}$, sebagai contoh untuk waktu yang sama (2,5 jam) rendemen yang dihasilkan pada suhu $70^{\circ} \mathrm{C}$ dan $90^{\circ} \mathrm{C}$ masing-masing sebesar $2,43 \%$ dan $1,70 \%$.
Pada waktu 1,5 jam, rendemen yang dihasilkan pada suhu $50^{\circ} \mathrm{C}$ relatif jauh lebih rendah dari hasil rendemen yang diperoleh pada suhu yang lain. Hal ini dikarenakan masih kurang optimalnya waktu dan suhu ekstraksi yang digunakan dalam proses tersebut. Di sisi lain, nilai rendemen maksimum yang dihasilkan mengalami penurunan yang cukup signifikan apabila dibandingkan untuk suhu $70^{\circ} \mathrm{C}$ dan $90^{\circ} \mathrm{C}$. Fenomena ini konsisten atau sesuai dengan hasil penelitian sebelumnya (Wulandari et. al., 2013) dan (Gudipati and Kannuchamy, 2013). Menurut kedua paper tersebut kenaikan suhu ekstraksi dapat menurunkan rendemen yang dihasilkan. Hal ini dikarenakan kemungkinan besar terjadinya reaksi hidrolisis lanjutan sebagian gelatin pada suhu yang tinggi. Sebagai efeknya, sebagian gelatin yang terbentuk akan terdegradasi dan mengakibatkan jumlah rendemen gelatin yang dihasilkan secara keseluruhan turun.

Gambar 1 menunjukkan bahwa pada suhu $50^{\circ} \mathrm{C}$ dan $90^{\circ} \mathrm{C}$ hasil rendemen gelatin mengalami kenaikan dengan bertambahnya waktu. Namun, pada suhu $70^{\circ} \mathrm{C}$, rendemen meningkat secara signifikan sampai 2,5 jam dan diikuti oleh penurunan nilai rendemen pada waktu 3 jam. Hasil tersebut sesuai dengan yang dilaporkan pada penelitian sebelumnya bahwa penambahan waktu ekstraksi akan meningkatkan rendemen gelatin (Tazwir et. al., 2014). Hal ini dimungkinkan karena jumlah ion $\mathrm{H}^{+}$sebagai agen penghidrolisis kolagen semakin banyak dan dengan waktu ekstraksi yang bertambah menyebabkan kolagen yang terkonversi menjadi gelatin lebih banyak. Namun, apabila waktu ekstraksi terlalu lama dengan konsentrasi asam yang terlalu tinggi dapat memicu reaksi hidrolisis lanjutan pada gelatin yang terbentuk.

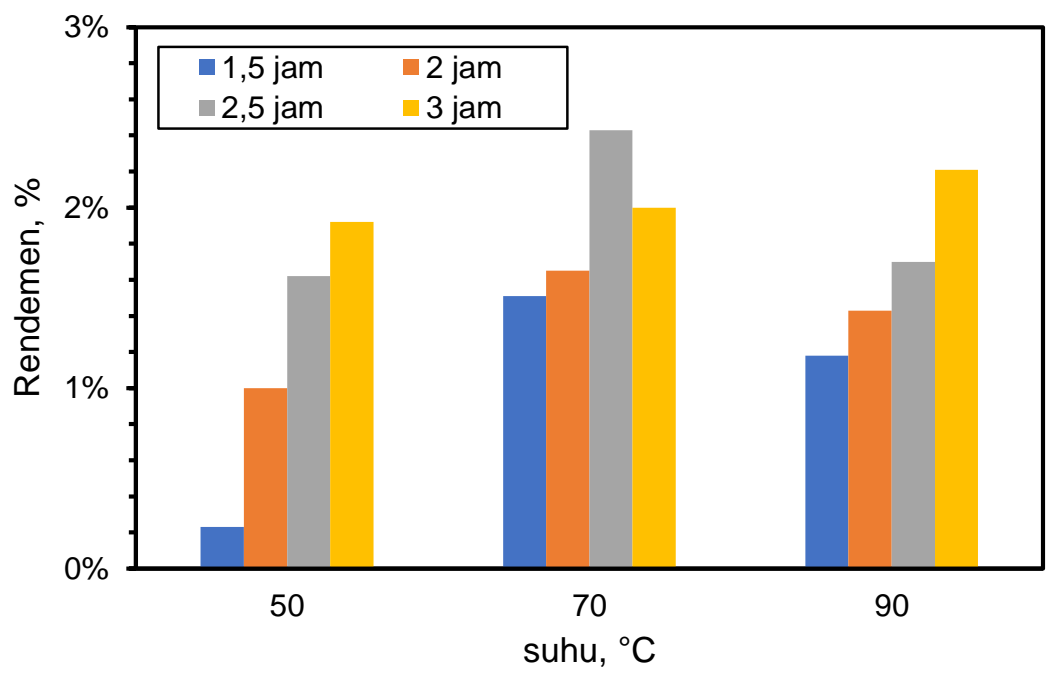

Gambar 1. Hubungan Rendemen gelatin dengan suhu ekstraksi pada berbagai waktu

Dari Gambar 2 terlihat bahwa pada suhu $50^{\circ} \mathrm{C}$ kadar air tertinggi diperoleh pada waktu ekstraksi 3 jam (sebesar 16\%), dan kadar air terendah pada waktu 2,5 jam (sekitar 7\%). Sedangkan, pada suhu $70^{\circ} \mathrm{C}$, kadar air tertinggi diperoleh saat waktu 1,5 jam dan 3 jam (sekitar 
$12 \%$ ), dan terendah pada waktu 2 jam (sebesar $8 \%$ ). Pada suhu $90^{\circ} \mathrm{C}$, kadar air tertinggi dihasilkan pada waktu 2 jam (13\%), sedangkan terendah terjadi pada waktu ekstraksi 3 jam, yaitu $5 \%$.

Dari gambar 2, terlihat bahwa pada waktu reaksi 3 jam, kadar air yang dihasilkan berbanding terbalik dengan peningkatan suhu. Hal ini sesuai dengan pernyataan bahwa kadar air yang dihasilkan dalam proses ekstraksi gelatin akan turun dengan dengan peningkatan suhu ekstraksi. Sifat gelatin yang mudah bereaksi dengan air menyebabkan perbedaan jumlah kadar air yang relatif jauh (Sompie et al., 2012). Berdasarkan kandungan kadar air, hampir semua sampel yang dihasilkan sudah memenuhi standar (GMIA, 2012). Kadar air yang dihasilkan berkisar antara 5\% sampai $13 \%$, kecuali untuk sampel pada suhu $50^{\circ} \mathrm{C}$ dan waktu 3 jam diperoleh kadar air $16 \%$.

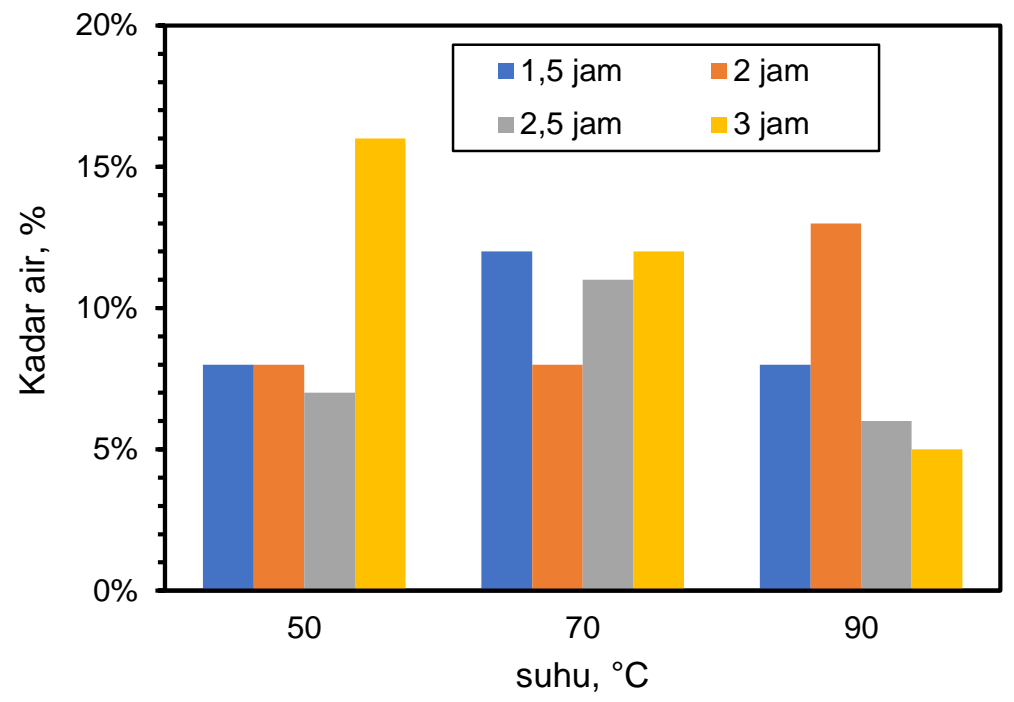

Gambar 2. Hubungan kadar air dalam gelatin dengan suhu ekstraksi pada berbagai waktu

Berdasarkan gambar 3, kadar abu yang diperoleh pada waktu 3 jam hampir sama untuk suhu reaksi (range $3 \%-3,1 \%$ ). Sedangkan pada suhu $70^{\circ} \mathrm{C}$ dan waktu 2,5 jam memberikan kecenderungan yang berbeda dibandingkan dengan waktu 1,5 jam dan 2 jam. Dimana, pada waktu 2,5 jam merupakan nilai optimum dan waktu 90 jam dan 2 jam merupakan nilai minimum kadar abu pada suhu tersebut. Suhu ektraksi $70^{\circ} \mathrm{C}$ dengan waktu proses selama 2 jam memberikan hasil kadar abu terendah, yaitu $2 \%$.

Pada suhu $70^{\circ} \mathrm{C}$, hasil kadar abu yang diperoleh pada semua waktu reaksi relatif tidak jauh berbeda. Hasil ini senada dengan penelitian terdahulu, yang menyatakan bahwa waktu ekstraksi merupakan faktor atau variabel yang relatif tidak berpengaruh secara signifikan pada hasil kadar abu pada gelatin (Tazwir et. al., 2014). Perubahan waktu ektraksi dari 1,5 jam menjadi 2 jam ada pada suhu $50^{\circ} \mathrm{C}$ dan $70^{\circ} \mathrm{C}$ menyebabkan terjadinya penurunan kadar abu. Hasil senada juga telah disampaikan oleh Tazwir et al. yang menjelaskan bahwa peningkatan suhu ekstraksi akan menurunkan kadar abu yang dihasilkan (Tazwir et. al., 2014). Namun, fenomena lain terjadi pada suhu $90^{\circ} \mathrm{C}$, di mana kadar abu yang dihasilkan jauh lebih tinggi dari pada suhu $70^{\circ} \mathrm{C}$. Kejadian ini disebabkan oleh proses asam yang diterapkan pada pembuatan gelatin ini. Asam yang ada dalam proses tersebut tidak selektif, sehingga selain mengekstrak komponen kolagen, juga non kolagen. Dan hasil samping atau pengotor (Impuritas) tersebut akan terikut ke dalam larutan. Berdasarkan hasil kadar abu dalam gelatin yang dihasilkan, maka dapat disimpulkan bahwa sampel gelatin yang dihasilkan pada berbagai suhu dan waktu reaksi belum memenuhi memenuhi standar (GMIA, 2012). Hal ini dikarenakan adanya komponen mineral yang terikat dalam kolagen dan belum terlepas pada saat pencucian. Sebagai akibatnya, kandungan mineral tersebut ikut terekstrak dan terbawa dalam gelatin yang dihasilkan. 


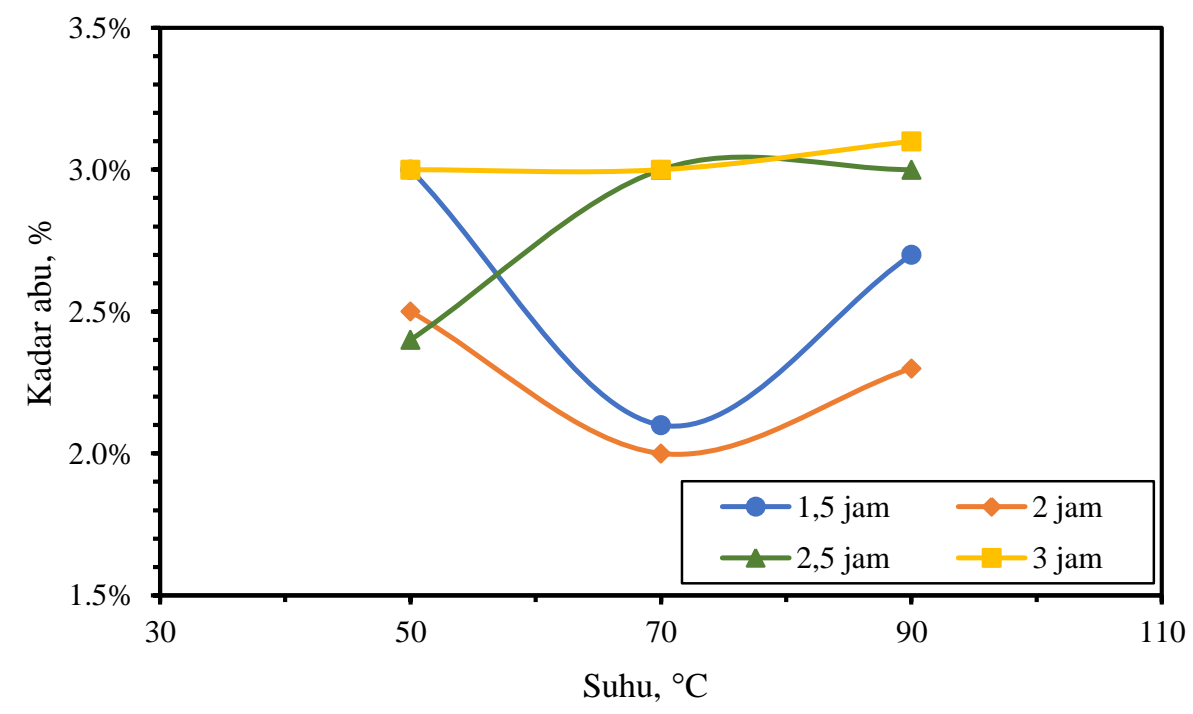

Gambar 3. Hubungan kadar abu dengan suhu ekstraksi pada berbagai waktu.

Pengaplikasian gelatin pada resep sirup mengikuti prosedur yang sudah dijelaskan sebelumnya. Gelatin yang dipilih adalah hasil yang terbaik dalam penelitian ini (dihasilkan dari reaksi yang dijalankan pada suhu $70^{\circ} \mathrm{C}$ dan waktu 2 jam). Viskositas sirup yang ditambahi gelatin hasil penelitian ini dibandingkan dengan yang ditambahi dengan gelatin komersial. Untuk memperoleh kekentalan atau viskositas yang sama dengan sirup dengan gelatin komersial dibutuhkan gelatin hasil penelitian dengan konsentrasi $7 \%$ harus dilarutkan dalam sirup tersebut. Berat jenis gelatin hasil percobaan adalah $1,257 \mathrm{~g} / \mathrm{ml}$, sirup komersil sebesar 1,247 $\mathrm{g} / \mathrm{ml}$, dan gelatin komersial sekitar 1,206 $\mathrm{g} / \mathrm{ml}$. Viskositas masing-masing dapat ditentukan dari berat jenisnya. Hasil perhitungan viskositas, $\mathrm{pH}$, kadar abu, kadar air ditunjukkan dalam Tabel 2.

Tabel 2. Hasil Karakteristik Gelatin Tulang Ikan Bandeng

\begin{tabular}{lccc}
\hline \multicolumn{1}{c}{ Karakteristik } & Standar GMIA & Gelatin komersial & Hasil Penelitian \\
\hline${\text { Kadar air }(\%)^{*}}_{\text {Kadar abu (\%) }}$ & $8-13$ & 12 & $8-13$ \\
Viskositas (cP) & $0,3-2$ & 2,1 & $2-3,1$ \\
pH & $1,5-7,5$ & 2,207 & 2,237 \\
${ }^{*}$ kecuali sampel pada suhu $50^{\circ} \mathrm{C}$ dan waktu 3 jam & 4,1 & 4,2 \\
\hline
\end{tabular}

*kecuali sampel pada suhu $50^{\circ} \mathrm{C}$ dan waktu 3 jam

↔SHIMADZU

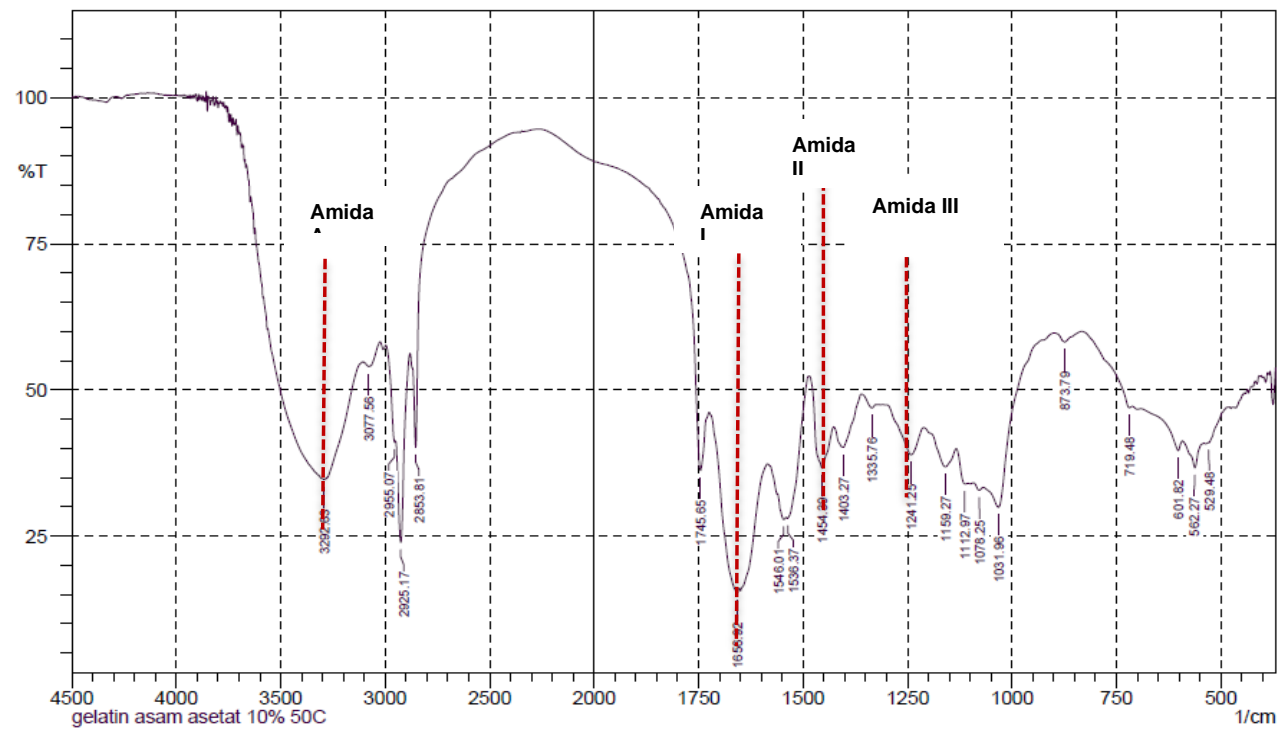

Gambar 4. Spektum FTIR gelatin yang dihasilkan untuk sampel yang dihasilkan pada reaksi dengan suhu $70^{\circ} \mathrm{C}$ dan waktu 2,5 jam 
Hasil uji analisis FTIR dari sampel yang dihasilkan pada ekstraksi dengan suhu $70^{\circ} \mathrm{C}$ dan waktu 2,5 jam ditunjukkan pada gambar 4 . Gambar tersebut menunjukkan keberadaan gugus fungsional komponen dalam gelatin terlihat dengan jelas. Gugus fungsinal yang dimaksud adalah seperti yang ada pada protein secara umum. Struktur tersebut antara lain karbon, gugus hiroksil $(\mathrm{OH})$, gugus hidrogen, gugus amina $(\mathrm{NH})$, karbonil $(\mathrm{C}=\mathrm{O})$, dan $\mathrm{C}-\mathrm{H}$ aromatis. Perkiraan gugus fungsional yang ada pada gambar 4, ditampilkan secara rinci dalam Tabel 3. Hasil tersebut sesuai dengan spektra yang terdapat pada gelatin sapi dan ikan komersial (Norziah et al., 2009). Daerah serapan khas amida A merupakan daerah yang menunjukkan adanya regangan $\mathrm{NH}$ dari gugus amida dengan $\mathrm{OH}$ dan ikatan hidrogen dari hidroksiprolina. Puncak serapannya berada pada panjang gelombang $3600 \mathrm{~cm}^{-1}-2300 \mathrm{~cm}^{-1}$ (Puspawati et. al., 2012). Gelatin tulang ikan bandeng ini menunjukkan serapan pada panjang gelombang $3292,63 \quad \mathrm{~cm}^{-1}$. Sedangkan, keberadaan komponen $\alpha$-helix yang menunjukkan adanya residu berada pada daerah serapan untuk amida I. Daerah ini terletak pada kisaran panjang gelombang 1661 $\mathrm{cm}^{-1}-1636 \mathrm{~cm}^{-1}$. Daerah ini juga berhubungan dengan sifat vibrasi peregangan gugus karbonil (Shah and Manekar, 2012). Pada gelatin ini, daerah amida I ditunjukkan pada panjang gelombang 1656,92 $\mathrm{cm}^{-1}$. Daerah serapan amida II menunjukkan asam amino prolina dan struktur rantai a berpilin. Puncak serapan ini terletak pada panjang gelombang $1560 \mathrm{~cm}^{-1}-1335 \mathrm{~cm}^{-1}$. Pada gelatin ini puncak serapan amida II berada pada panjang gelombang $1454,39 \mathrm{~cm}^{-1}$. Daerah serapan amida III berada pada panjang gelombang 1300 $\mathrm{cm}^{-1}-1200 \mathrm{~cm}^{-1}$. Daerah ini menunjukkan hilangnya struktur triple helix akibat perubahan $\alpha$-helix menjadi random coil. Hal itu juga berarti bahwa kolagen pada tulang ikan bandeng telah berhasil dihilangkan selama proses ekstraksi gelatin (Muyonga et. al., 2004). Pada gelatin ini diperoleh puncak serapan amida III pada panjang gelombang 1241,25 $\mathrm{cm}^{-1}$.

Tabel 3. Gugus fungsional dari gelatin yang dihasilkan

\begin{tabular}{cclccl}
\hline No & Peak & $\begin{array}{c}\text { Perkiraan gugus } \\
\text { fungsional }\end{array}$ & No & Peak & $\begin{array}{c}\text { Perkiraan gugus } \\
\text { fungsional }\end{array}$ \\
\hline 1 & 529.48 & C-Br & 12 & 1403.27 & C-H alkana \\
2 & 562.27 & C-Br & 13 & 1454.39 & C-H alkana \\
3 & 601.82 & C-Br & 14 & 1536.37 & C=C aromatic \\
4 & 719.48 & C-H aromatik & 15 & 1546.01 & C=C aromatic \\
5 & 873.79 & C-H aromatik & 16 & 1656.92 & C=C aromatic \\
6 & 1031.96 & C-O ester & 17 & 1745.65 & C=O stretching \\
7 & 1078.25 & C-O ester & 18 & 2853.81 & C-H alkana \\
8 & 1112.97 & C-O ester & 19 & 2925.17 & C-H alkana \\
9 & 1159.27 & C-O ester & 20 & 2955.07 & C-H alkana \\
10 & 1241.25 & C-N amina & 21 & 3077.56 & C-H alkena \\
11 & 1335.76 & C-N amina & 22 & 3292.63 & NH stretching \\
\hline
\end{tabular}

\section{KESIMPULAN}

Rendemen tertinggi (sekitar 2,43\%) diperoleh pada ekstraksi dengan suhu $70^{\circ} \mathrm{C}$ dan waktu 2,5 jam. Kadar air terendah diperoleh pada suhu $90^{\circ} \mathrm{C}$ terjadi saat 3 jam waktu ekstraksi, yaitu $5 \%$. Ekstraksi pada suhu $70^{\circ} \mathrm{C}$ dan waktu 2 jam menghasilkan kadar abu terendah, yaitu sebesar $2 \%$. Berdasarkan syarat kadar abu dan kadar air, gelatin hasil penelitian ini sudah sesuai dengan Standar Mutu gelatin (GMIA, 2012). Konsentrasi gelatin yang dibutuhkan dalam pengentalan sirup untuk memperoleh hasil yang sesuai dengan sirup komersial adalah 7\%.

\section{DAFTAR PUSTAKA}

Aleman, A., and O. Martinez-Alvarez. 2013. "Marine Collagen as a Source of Bioactive Molecules: A Review." The Natural Products Journal 3 (2): 105-14. https://doi.org/10.2174/2210315511303020 005.

AOAC. 2016. "The Official Methods of Analysis of AOAC International." Association of Official Analytical Chemist 20th ed.

Candra, A. N., and A. H. Setiawan. 2013. "Analisis Prospek Dan Perkembangan Usaha Industri Bandeng Presto Di Kota Semarang." Diponegoro Journal of Economics 2: 1-11. 
Chen, J., Y. Liu, G. Wang, S. Sun, R. Liu, B. Hong, R. Gao, and K. Bai. 2018. "Processing Optimization and Characterization of Angiotensin-IConverting Enzyme Inhibitory Peptides from Lizardfish (Synodus Macrops) Scale Gelatin." Marine Drugs $16 \quad$ (7). https://doi.org/10.3390/md16070228.

Chun, Y. Y., J. K. Wang, N. S. Tan, P. P. Y. Chan, T. T. Y. Tan, and C. Choong. 2016. "A Periosteum-Inspired 3D HydrogelBioceramic Composite for Enhanced Bone Regeneration." Macromolecular Bioscience 16 (2): 276-87. https://doi.org/10.1002/mabi.201500258.

Elango, J., J. Zhang, B. Bao, K. Palaniyandi, S. Wang, W. Wenhui, and J. S. Robinson. 2016. "Rheological, Biocompatibility and Osteogenesis Assessment of Fish Collagen Scaffold for Bone Tissue Engineering." International Journal of Biological Macromolecules 91: 51-59. https://doi.org/10.1016/j.ijbiomac.2016.05.0 67.

GMIA. 2012. "Gelatin Handbook." Gelatin Manufacturers Institute of America Members as of January 2012.

Gudipati, V., and N. Kannuchamy. 2013. "Recovery of Gelatin with Improved Functionality from Seafood Processing Waste." In Kim SK. (Eds) Seafood Processing By-Products, 145-69. https://doi.org/https://doi.org/10.1007/9781-4614-9590-1 8.

Haddar, A., S. Sellimi, R. Ghannouchi, O. M. Alvarez, M. Nasri, and A. Bougatef. 2012. "Functional, Antioxidant and Film-Forming Properties of Tuna-Skin Gelatin with A Brown Algae Extract." International Journal of Biological Macromolecules 51 (4): 47783.

https://doi.org/10.1016/j.ijbiomac.2012.06.0 16.

Hanani, Z. A. Nur. 2015. "Gelatin.” Encyclopedia of Food and Health 3: 191-95. https://doi.org/10.1016/B978-0-12-3849472.00347-0.

Hidayat, G., E. N. Dewi, and L. Rianingsih. 2016. "Characteristics of Bone Gelatin Tilapia (Oreochromis Niloticus) Processed by Using Hydrolysis with Phosphoric Acid and Papain Enzyme." Jurnal Pengolahan Hasil Perikanan Indonesia 19 (1): 69-78. https://doi.org/10.17844/jphpi.2016.19.1.69

Huang, C. Y., Y. H. Tsai, Y. H. Hong, S. L. Hsieh, and R. H. Huang. 2018. "Characterization and Antioxidant and Angiotensin I-Converting Enzyme (ACE)Inhibitory Activities of Gelatin Hydrolysates Prepared from Extrusion-Pretreated Milkfish (Chanos Chanos) Scale." Marine
Drugs $\quad 16 \quad$ (10): $1-20$. https://doi.org/10.3390/md16100346.

Jamilah, B., and K. G. Harvinder. 2002. "Properties of Gelatins from Skins of Fish Black Tilapia (Oreochromis Mossambicus) and Red Tilapia (Oreochromis Nilotica)." Food Chemistry 77 (1): 81-84. https://doi.org/10.1016/S0308-

8146(01)00328-4.

Karim, A. A., and R. Bhat. 2009. "Fish Gelatin: Properties, Challenges, and Prospects as An Alternative to Mammalian Gelatins." Food Hydrocolloids 23 (3): 563-76. https://doi.org/10.1016/j.foodhyd.2008.07.0 02.

Katili, A. S. 2013. "Struktur Dan Fungsi Protein Dan Enzim." JURNAL PELANGI ILMU 2 (5): 54 .

Liu, D., M. Nikoo, G. Boran, P. Zhou, and J. M. Regenstein. 2015. "Collagen and Gelatin." Annual Review of Food Science and Technology 6: 527-57. https://doi.org/10.1146/annurev-food031414-111800.

Marzuki, A., E. Pakki, and D. F. Zulfikar. 2011. "Ekstraksi Dan Penggunaan Gelatin Dari Limbah Tulang lkan Bandeng (Chanos Chanos Forskal) Sebagai Emulgator Dalam Formulasi Sediaan Emulsi." Majalah Farmasi Dan Farmakologi 15 (2): 63-68.

Masirah. 2018. "Perbandingan Karakteristik Sifat Fisikokimia Gelatin Tulang Ikan." In Prosiding Seminar Nasional Kelautan Dan Perikanan IV 2018, 285-92.

Muyonga, J. H., C. G. B. Cole, and K. G. Duodu. 2004. "Fourier Transform Infrared (FTIR) Spectroscopic Study of Acid Soluble Collagen and Gelatin from Skins and Bones of Young and Adult Nile Perch (Lates Niloticus)." Food Chemistry 86 (3): 325-32.

https://doi.org/10.1016/j.foodchem.2003.09 .038 .

Neves, A. C., P. A. Harnedy, M. B. O'Keeffe, M. A. Alashi, R. E. Aluko, and R. J. FitzGerald. 2017. "Peptide Identification in A Salmon Gelatin Hydrolysate with Antihypertensive, Dipeptidyl Peptidase IV Inhibitory and Antioxidant Activities." Food Research International 100 (June): 112-20. https://doi.org/10.1016/j.foodres.2017.06.0 65.

Norziah, M. H., A. Al-Hassan, A. B. Khairulnizam, M. N. Mordi, and M. Norita. 2009. "Characterization of Fish Gelatin from Surimi Processing Wastes: Thermal Analysis and Effect of Transglutaminase on Gel Properties." Food Hydrocolloids 23 (6): 1610-16. https://doi.org/10.1016/j.foodhyd.2008.12.0 04.

Puspawati, N., I Simpen, and I S. Miwada. 2012. 
"Isolasi Gelatin Dari Kulit Kaki Ayam Broiler Dan Karakterisasi Gugus Fungsinya Dengan Spektrofotometri FTIR." Jurnal Kimia 6 (1): 79-87.

Richard, M., and L. Albert. 2008. Updated Biochemistry Text Recommended. Vol. 5. https://doi.org/10.2307/1309148.

Schrieber, R., and H. Gareis. 2007. Gelatin Handbook: Theory and Industrial Practice. https://doi.org/10.1002/9783527610969.

Shah, V., and A. Manekar. 2012. "Isolation and Characterization of Collagen from The Placenta of Buffalo (Bovidae Bubalus Bubalis) for The Biomaterial Applications." Trend in Life Science 1 (4): 26-32.

Sompie, M., S. Triatmojo, A. Pertiwiningrum, and Y. Pranoto. 2012. "The Effects of Animal Age and Acetic Acid Concentration on Pigskin Gelatin Characteristics." Journal of the Indonesian Tropical Animal Agriculture $37 \quad$ (3): 176-82. https://doi.org/10.14710/jitaa.37.3.176-182.

Tazwir, T., D. L. Ayudiarti, and R. Peranginangin. $2014 . \quad$ "Optimasi Pembuatan Gelatin Dari Tulang Ikan KaciKaci (Plectorhynchus Chaetodonoides Lac.) Menggunakan Berbagai Konsentrasi Asam Dan Waktu Ekstraksi." Jurnal Pascapanen Dan Bioteknologi Kelautan Dan Perikanan 2 (1): 35. https://doi.org/10.15578/jpbkp.v2i1.26.
Temofeew, N. A., K. R. Hixon, S. H. McBrideGagyi, and S. A. Sell. 2017. "The Fabrication of Cryogel Scaffolds Incorporated with Poloxamer 407 for Potential Use in The Regeneration of The Nucleus Pulposus." Journal of Materials Science: Materials in Medicine 28: 36. https://doi.org/10.1007/s10856-016-5824-0. Wulandari, A. Supriadi, and B. Purwanto. 2013. "Pengaruh Defatting Dan Suhu Ekstraksi Terhadap Karakteristik Fisik Gelatin Tulang Ikan Gabus (Channa Striata)." FishtecH 2 (1): 38-45.

Zhang, L., S. Zhang, H. Song, and B. Li. 2018. "Effect of Collagen Hydrolysates from Silver Carp Skin (Hypophthalmichthys Molitrix) on Osteoporosis in Chronologically Aged Mice: Increasing Bone Remodeling." Nutrients 10 (10). 